\title{
Effect of soil and crop management practices on sodicity stress alleviation and rice productivity under water scarce condition
}

\section{P. Janaki*}

Anbil Dharmalingam Agricultural College \& Research Institute, Tamil Nadu Agricultural University, Tiruchirappalli-620027 (Tamil Nadu), India

\section{A. Alagesan}

Anbil Dharmalingam Agricultural College \& Research Institute, Tamil Nadu Agricultural University, Tiruchirappalli-620027 (Tamil Nadu), India

\section{J. Ejilane}

Anbil Dharmalingam Agricultural College \& Research Institute, Tamil Nadu Agricultural University, Tiruchirappalli-620027 (Tamil Nadu), India

\section{S. Nithila}

Anbil Dharmalingam Agricultural College \& Research Institute, Tamil Nadu Agricultural University, Tiruchirappalli-620027 (Tamil Nadu), India

\section{P. Balasubramaniam}

Anbil Dharmalingam Agricultural College \& Research Institute, Tamil Nadu Agricultural University, Tiruchirappalli-620027 (Tamil Nadu), India

\section{P. Santhy}

Anbil Dharmalingam Agricultural College \& Research Institute, Tamil Nadu Agricultural University, Tiruchirappalli-620027 (Tamil Nadu), India

${ }^{*}$ Corresponding author. Email: janaki.p@tnau.ac.in

\section{Article Info}

https://doi.org/10.31018/

jans.v13i4.2930

Received: August 16, 2021

Revised: October 26, 2021

Accepted: November 3, 2021

\section{How to Cite}

Janaki, P. et al. (2021). Effect of soil and crop management practices on sodicity stress alleviation and rice productivity under water scarce condition. Journal of Applied and Natural Science, 13(4), 1238 - 1248. https://doi.org/10.31018/jans.v13i4.2930

\begin{abstract}
The prominent issue faced by the farmers of Cauvery Delta regionin Tamil Nadu particularly Tiruchirapalli District is the lack of timely release of water for rice nursery preparation and transplanting. Hence wet seeding of rice is recommended for timely cultivation. On the other hand, sodic nature of the soil warrants rice cultivation only. Therefore, the present investigation was carried out to study the different soil and crop management practices on alleviating sodicity stress and improving rice (variety ADT 3) productivity under water-scarce conditions. The experiment was laid in a split plot design with six mainplots,including rice wet seeding, daincha (Sesbania aculeata) application as green manure, anti-oxidant microbial consortia (AOMC) spray and four sub-plots with graded levels of NPK based on soil test values with three replication. Results showed that the daincha incorporation @ 6.25 t/ha followed by rice wet seeding + AOMC spray @1.5\% with $125 \%$ soil test based NPK had significantly increased thechlorophyll content, SPAD values, proline content and grain and straw yields which remained on par with daincha incorporation @ 6.25 t/ha followed by rice wet seeding + AOMC spray @1.5\% with $100 \%$ soil test based NPK.Significantly lower ESP at $5 \%$ level and higher phosphatase activity in soil was also recorded by daincha incorporation @ 6.25 t/ha followed by rice wet seeding + AOMC spray @1.5\% with $125 \%$ and $100 \%$ soil test based NPK. Gross return, net return and B:C ratio were also higher in the plot, which received daincha incorporation @6.25 t/ha followed by rice wet seeding + AOMC spray @1.5 $\%$ with $100 \%$ soil test based NPK. The present study reveals that the inclusion of ectophytic microbial population spray in rice plants and the management practices helps the crop to tolerate the sodicity stress under water-scarce condition by maintaining required physiological functions like proline synthesis and enzyme activities etc which need to be further explored at the genotypic level.
\end{abstract}

Keywords: Anti-oxidant microbes, Daincha green manuring, Sodicity, Wet Seeded rice

\section{INTRODUCTION}

Rice is the staple food crop for $50 \%$ population in the world (Lou et al., 2012) and $90 \%$ of rice is grown in
Asia and $20 \%$ is from India. Though the rice is a high yielding crop with an average production potential of 10 $\mathrm{t} \mathrm{ha}^{-1}$, its yield production is 10 to $15 \%$ lower than its potential due to environmental stresses (biotic or abiot- 
ic), management strategies, and nutrients deficiencies (Sajid et al., 2017). Abiotic stresses are the major causes which affect the physiology of crop by altering its metabolism, growth, and development either directly or indirectly. Apart from drought, sodicity and salinity are the major abiotic stresses in arid and semiarid regions that substantially limit the crop production and reduce the average yield of major crops by more than $50 \%$ (Bray et al., 2000). Worldwide more than 1000 million hectares of land is affected by salinity or sodicity and over $50 \%$ of world's population lives in 13 countries affected severely by soil salinity (Chen et al., 2021).

Rice production in salt-affected soils is harshly reduced by poor physical constraints caused by the alkaline hydrolysis products such as sodium carbonate and bicarbonates together with sufficient exchangeable sodium. Due to salt stress, these soils are also intrinsically low in organic matter and available $\mathrm{N}$ and have poor microbial activity (Kumar and Sharma, 2020). The crop is greatly sensitive to salinity and sodicity at the early seedling stage, affecting the crop establishment and increasing the mortality rate. Hence, high sodium ion in rhizosphere inhibits $\mathrm{K}+$ uptake and high $\mathrm{Na}$ uptake cause express cellular injury to plants (Rahman et al., 2017). Incorporation of green manures, application of extra nitrogen and cultivating salt tolerant varieties is the common practices recommended for crop cultivation after ameliorating the sodic soil (Latha and Janaki, 2016).

In Tamil Nadu, rice is cultivated in an area of $1.83 \mathrm{~m}$.ha with a production of $5.84 \mathrm{mt}$ with major area in Cauvery Delta zone. Its cultivation period completely depends on river water release (Amrutha and Santhy, 2018). To reduce the time requirement for field preparation and cultivate rice matching the water release period, farmers of this region are adopting Wet Seeded Rice (WSR) technique. Though thisshift though helps to reduce water requirement and favors the timely cultivation of rice, still farmers are facing issues of water scarcity and saline-sodicity induced stresses in rice production. Hence the development of collective soil and crop management practices for improving the rice productivity in sodic soil under scarce conditions is the need of the hour. With this background, the present study was conducted to identify the suitable soil and crop management practices for improving the direct wetseeded rice yield in sodic soil under water-scarce conditions involving green manuring and foliar spray of anti-oxidant microbial consortia.

\section{MATERIALS AND METHODS}

The experiment was carried out during rabi 2018-19 at Anbil Dharmalingam Agricultural College \& Research
Institute Farm, Tamil Nadu Agricultural Farm (TNAU), Tiruchirapalli. The farm is situated in the Cauvery Delta Zone of Tamil Nadu at $10^{\circ} 45^{\prime} \mathrm{N}$ latitude and $78^{\circ} 36^{\prime} \mathrm{E}$ longitude with an altitude of $85 \mathrm{~m}$ above MSL. The experimental soil was sandy clay loam in texture have the $\mathrm{pH} 8.90$, EC $0.39 \mathrm{dS} / \mathrm{m}$, ESP - $32 \mathrm{c} . \mathrm{mol}(\mathrm{p}+) / \mathrm{kg}$, organic carbon $0.58 \%$. The available $\mathrm{N}, \mathrm{P}$, and $\mathrm{K}$ status was found to be low, medium and low, respectively. The normal climatic condition of the location (mean of 30 years) was as follows: Mean annual rainfall of $815 \mathrm{~mm}$ distributed over 41 rainy days. The annual mean maximum and minimum temperatures were 36 and $32^{\circ} \mathrm{C}$, respectively. The relative humidity ranges from 65 to 90 per cent in the $\mathrm{FN}$ and 43 to 50 per cent in the AN. The mean bright sunshine hours per day are 8.2 hours with mean solar radiation of $475 \mathrm{cal} \mathrm{cm}^{-2} \mathrm{~min}^{-1}$. During the experimental period, total rainfall of $131 \mathrm{~mm}$ was received in 15 rainy days. The mean maximum and minimum temperatures were 22.3 and $32.7^{\circ} \mathrm{C}$, respectively. The mean relative humidity was 85 per cent in the FN and 58.2 percent in the AN. The mean sunshine hours were 5.8 .

\section{Experiment details}

The experiment was laid in split plot design with six main plots and four sub-plots (of $5 \mathrm{~m} \mathrm{x4} \mathrm{m)} \mathrm{with} \mathrm{three}$ replication using long duration salt tolerant rice variety TRY 3 as test crop. The main plot treatments are $: \mathrm{M}_{1}$ : Rice transplanting ; $M_{2}$ : Rice wet seeding ; $M_{3}$ : Daincha(Sesbania aculeata) incorporation followed by rice wet seeding $; \mathrm{M}_{4}$ : Rice wet seeding + Daincha inter cropping ; $\mathrm{M}_{5}$ : Daincha incorporation fb rice wet seeding + anti oxidant microbial consortia (AOMC); $M_{6}$ : Rice wet seeding + Daincha inter cropping + anti oxidant microbial consortia (AOMC). The sub plots consisted of $\mathrm{S}_{1}$ : Control ; $\mathrm{S}_{2}: 75 \%$ soil test based NPK ; $\mathrm{S}_{3}: 100 \%$ soil test based NPK ; $\mathrm{S}_{4}: 125 \%$ soil test based NPK. The 100 per cent soil test based $\mathrm{N}: \mathrm{P}_{2} \mathrm{O}_{5}: \mathrm{K}_{2} \mathrm{O}$ was worked out to be 196: 75: 75 NPK kg/ ha which was calculated through Decision Support System for Integrated Fertilizer Recommendation (DSSIFER) software of TNAU, Coimbatore using the initial soil test values of available N, P and K. According to the treatments, 75 and 125 per cent of the soil test based NPK fertilizer levels was applied. Entire quantity of $\mathrm{P}$ and 25 per cent of $\mathrm{N}$ and $\mathrm{K}$ fertilizers were applied at the time of sowing and remaining 75 per cent of $\mathrm{N}$ and $\mathrm{K}$ fertilizers were top dressed in three equal splits at active tillering, panicle initiation and heading stage of rice. The AOMC consisting of Bacillus subtilis, B.polymyxa and Pseudomonas species isolated from native sodic soil was prepared in liquid formulation and sprayed during boot leaf and panicle initiation stages of the crop. These isolates would be deposited at (MTCC) IMTECH, Chandigarh for getting accession number. 
Janaki, P. et al. / J. Appl. \& Nat. Sci. 13(4), 1238 - 1248 (2021)

\section{Analysis of physiological parameters in plant and soil properties}

Proline content was estimated at the flowering stage. Free proline was extracted according to the method of Bates et al. (1973). Total chlorophyll content was estimated following the method Yoshida et al. (1971) suggested and expressed as $\mathrm{mg} \mathrm{g}^{-1}$ fresh weight. SPAD readings were recorded using Chlorophyll Meter (SPAD 502). The availability of nutrients in the soil at the time of harvest was assessed as described by Jackson (1973). The Exchangeable sodium percentage (ESP) was calculated as described by Janaki et al. (2020) for sodic soils. The activity of enzymes viz., urease, phosphatase and dehydrogenase in soil were assessed as reported by Tabatabai and Bremner (1969 \&1972) and Casida et al. (1964).

The harvested plants from the net plot area were thrashed manually and each plot yield was separately sun-dried, cleaned, winnowed and weighed. Grain yield was computed at 14 per cent moisture content and expressed in $\mathrm{kg} / \mathrm{ha}$.

\section{Statistical analysis}

The data collected from the field experiment was statistically analyzed following the procedure given by Gomez and Gomez (2010) for split plot design. Whenever significant difference existed, critical difference was constructed at five per cent probability level. Such of those treatments where the differences are not significant were denoted as NS.

\section{RESULTS AND DISCUSSION}

Rice wet seeding is the recommended practice in the Cauvery Delta region to reduce the water requirement and for timely cultivation. Delay in water release affects the nursery preparation and further transplanting. On the other hand, the sodic nature of the soil warrants only rice cultivation but with less productivity. Many plant-growth-promoting rhizobacteria are known for providing protection to the plants from stressed environment. However, the survival of microorganism in stressed habitat is possible due to their ability of utilizing the resources available under that suitable niche (Damodaran et al., 2014). Hence the effect of foliar spray of anti-oxidant microbial consortia on helping the rice growth at stressed environment might be useful and is evaluated along with other soil and crop management practices. The rice growth and yield related parameters recorded during the crop growing period and the results of soil analysis obtained are given in tables 1-6.

\section{Physiological parameters}

Chlorophyll concentration is an indicator of tissue tolerance to saline-sodicity in soil. Hence the total chloro- phyll content and chlorophyll meter reading recorded at panicle initiation and flowering stages (Table 1 and 2). Both main and sub plot treatments and their interaction recorded significant difference $(p=0.05)$. The daincha incorporation followed by rice wet seeding + AOMC + $125 \%$ of soil test based NPK recorded maximum total chlorophyll content (3.34) among the interaction treatments at panicle initiation stage and was on par with rice wet seeding + daincha inter cropping + AOMC+ $125 \%$ of soil test based NPK (3.11). Similar results were obtained during the flowering stage also.Incorporation of daincha and extra dose of NPK might have improved the rooting structure, increasing the availability and balanced uptake of $\mathrm{N}$ by the crop and hence might increase the leaf chlorophyll content. A similar result was reported by Islam et al. (2019) that the balanced nutrients supply in combination with Sesbania aculeata as green manure increased the leaf chlorophyll content in rice. The SPAD value is the indirect estimation of chlorophyll content. SPAD value increased from panicle initiation to flowering stage and declined towards maturity. The daincha incorporation followed by rice wet seeding + AOMC recorded the maximum value of 48.3 at the flowering stage. Among the sub plot treatments, $125 \%$ soil test based NPK. (46) was found to be effective, followed by $100 \%$ soil test based NPK (44). This showed that the application of increased NPK in sodic soil enhances their uptake and rice growth. The combined application of daincha and $A O M C$ increased the soil available nutrients and crop utilization and hence recorded higher SPAD values. The effect of green manuring with Sesbania rostrata on increasing the SPAD values in rice at different growth stages was also reported by Janaki et al. (2000) and Janaki and Thiaygarajan (2005).

Foliar spray of AOMC recorded higher chlorophyll and SPAD values which could be ascribed to production of osmolytes to maintain cell turgidity and metabolism to survive against osmotic stress in sodic condition. Further, the daincha incorporation might have also produced organic acids and polysaccharides and maintained a favorable microbial population, increasing the nutrient's availability by reducing the $\mathrm{Na}$ uptake. Effect of exopolysaccharides produced by bacteria Azotobacter chroococcum in the root zone on alleviating the salt stress by reducing $\mathrm{Na}$ uptake by the crop has been also reported by Arora et al. (2010). Shultana et al. (2020) also identified significant improvement in total chlorophyll content when rice was inoculated with $\mathrm{Ba}$ cillus tequilensis.

Proline is one of the osmolyte to assess the salt tolerance capacity of the crops. Hence the variation in proline content due to imposed management practices was studied. The data on proline content of rice revealed that there was a gradual accumulation of proline from panicle initiation to flowering stage (Table 3). 
Table 1. Effect of different management practices and fertilizer levels on total chlorophyll $\left(\mathrm{mg} \mathrm{g}^{-1}\right)$ content in rice at panicle initiation and flowering stages

\begin{tabular}{|c|c|c|c|c|c|c|c|}
\hline $\begin{array}{l}\text { Main plots/sub } \\
\text { plots }\end{array}$ & $M_{1}$ & $\mathbf{M}_{2}$ & $\mathbf{M}_{3}$ & $M_{4}$ & $M_{5}$ & $M_{6}$ & Mean \\
\hline \multicolumn{8}{|c|}{ Panicle Initiation stage } \\
\hline Control & 2.28 & 2.22 & 2.34 & 2.32 & 2.57 & 2.49 & 2.37 \\
\hline $75 \%$ ST-NPK & 2.48 & 2.37 & 2.57 & 2.56 & 2.78 & 2.60 & 2.56 \\
\hline $100 \%$ ST-NPK & 2.57 & 2.49 & 2.70 & 2.68 & 3.11 & 3.07 & 2.77 \\
\hline $125 \%$ ST-NPK & 2.85 & 2.63 & 3.07 & 2.94 & 3.34 & 3.11 & 2.99 \\
\hline \multirow[t]{2}{*}{ Mean } & 2.54 & 2.42 & 2.67 & 2.63 & 2.95 & 2.82 & \\
\hline & M & S & $M \times S$ & $S \times M$ & & & \\
\hline $\mathrm{CD}(\mathrm{P}=0.05)$ & 0.053 & 0.021 & 0.069 & 0.051 & & & \\
\hline \multicolumn{8}{|l|}{ Flowering stage } \\
\hline Control & 2.44 & 2.33 & 2.53 & 2.41 & 2.58 & 2.44 & 2.45 \\
\hline $75 \%$ ST-NPK & 2.51 & 2.45 & 2.71 & 2.72 & 2.77 & 2.46 & 2.60 \\
\hline $100 \%$ ST-NPK & 2.65 & 2.52 & 2.91 & 2.82 & 3.08 & 3.09 & 2.84 \\
\hline $125 \%$ ST-NPK & 2.95 & 2.72 & 3.12 & 3.06 & 3.15 & 3.10 & 3.01 \\
\hline \multirow[t]{2}{*}{ Mean } & 2.63 & 2.50 & 2.82 & 2.75 & 2.89 & 2.77 & \\
\hline & M & $S$ & $M \times S$ & $S \times M$ & & & \\
\hline$C D(P=0.05)$ & 0.152 & 0.062 & 0.200 & 0.152 & & & \\
\hline
\end{tabular}

$\mathrm{M}_{1}$ : Transplanted rice; $\mathrm{M}_{2}$ : Wet seeded rice; $\mathrm{M}_{3}$ : Wet seeded rice+ Daincha incorporation; $\mathrm{M}_{4}$ - Wet seeded rice+ Daincha intercropping; $M_{5}$ : Wet seeded rice+ Daincha incorporation+ AOMC; $M_{6}$ - Wet seeded rice+Daincha intercropping+AOMC; ST-NPK: Soil test based NPK

Table 2. Effect of different management practices and fertilizer levels on SPAD value in rice at panicle initiation and flowering stages

\begin{tabular}{|c|c|c|c|c|c|c|c|}
\hline $\begin{array}{l}\text { Main plots/ sub } \\
\text { plots }\end{array}$ & $M_{1}$ & $M_{2}$ & $M_{3}$ & $\mathbf{M}_{4}$ & $\mathbf{M}_{5}$ & $M_{6}$ & Mean \\
\hline \multicolumn{8}{|c|}{ Panicle Initiation stage } \\
\hline Control & 34.4 & 24.0 & 32.0 & 29.5 & 37.4 & 40.0 & 32.9 \\
\hline $75 \%$ ST-NPK & 40.0 & 30.0 & 38.0 & 35.4 & 37.4 & 43.0 & 37.3 \\
\hline $100 \%$ ST-NPK & 44.0 & 35.0 & 42.0 & 39.3 & 39.3 & 45.0 & 40.8 \\
\hline $125 \%$ ST-NPK & 45.0 & 40.0 & 39.3 & 37.4 & 41.3 & 51.0 & 42.3 \\
\hline \multirow[t]{2}{*}{ Mean } & 40.9 & 32.3 & 37.8 & 35.4 & 38.8 & 44.8 & \\
\hline & M & S & $M \times S$ & $S \times M$ & & & \\
\hline$C D(P=0.05)$ & 3.06 & 1.39 & 4.50 & 4.10 & & & \\
\hline \multicolumn{8}{|l|}{ Flowering stage } \\
\hline Control & 39.3 & 30.0 & 35.0 & 34.4 & 44.3 & 43.0 & 37.7 \\
\hline $75 \%$ ST-NPK & 44.0 & 38.0 & 40.0 & 39.3 & 34.4 & 45.0 & 40.1 \\
\hline $100 \%$ ST-NPK & 47.0 & 40.0 & 44.0 & 43.3 & 39.3 & 50.0 & 43.9 \\
\hline $125 \%$ ST-NPK & 48.0 & 42.0 & 42.3 & 44.3 & 44.3 & 55.0 & 46.0 \\
\hline \multirow[t]{2}{*}{ Mean } & 44.6 & 37.5 & 40.3 & 40.3 & 40.6 & 48.3 & \\
\hline & M & $S$ & $M \times S$ & $S \times M$ & & & \\
\hline$C D(P=0.05)$ & 3.36 & 1.51 & 4.64 & 3.70 & & & \\
\hline
\end{tabular}

$M_{1}$ : Transplanted rice; $M_{2}$ : Wet seeded rice; $M_{3}$ : Wet seeded rice+Daincha incorporation; $M_{4}$ - Wet seeded rice+ Daincha intercropping; $M_{5}$ : Wet seeded rice+ Daincha incorporation + AOMC; $M_{6}$ - Wet seeded rice+ Daincha intercropping+ AOMC; ST-NPK: soil test based NPK 
Janaki, P. et al. / J. Appl. \& Nat. Sci. 13(4), 1238 - 1248 (2021)

Among the different management practices, rice wet seeding + daincha inter cropping + AOMC recorded a significantly higher amount of proline activity at the panicle initiation stage, which was on par with daincha incorporation followed by rice wet seeding + AOMC spray. Among the graded NPK levels, significantly $(p=0.05)$ higher proline content was recorded by $125 \%$ soil test based NPK plot and was on par with $100 \%$ soil test based NPK. The interaction effect was found to be significantly different among the treatment combinations. The results showed that the daincha intercropping with AOMC spray and an extra $25 \% \mathrm{~N}$ helps the direct seed rice to develop defense mechanisms for ionic and osmotic stresses caused by the sodicity. The role of proline in cell osmotic adjustment, membrane stabilization and detoxification of injurious ions in plants exposed to salt stress is widely reported (Rahman et al., 2017). Hence, the osmotic adjustment is one of the major physiological phenomena vital for sustaining the growth of plants under osmotic stress. The influence of microorganisms like Pseudomonas fluorescent on the accumulation of proline under osmotic stress has also been reported (Ansary et al., 2012) and under stress conditions, proline protects plants from damage because it can scavenge ROS (Natarajan et al., 2012).

\section{Grain and straw yield}

Significantly higher rice grain and straw yield were recorded by daincha incorporation followed by rice wet seeding + AOMC spray, which was on par with rice wet seeding +daincha inter cropping + AOMC spray (Table
4). Among the main plots, the lower yield was recorded under rice transplanting and was on par with rice wet seeding. Under different fertilizer levels, yield was higher with $125 \%$ soil test-based NPK which was on par with $100 \%$ soil-based NPK. The interaction effect was found to be significant. The rice wet seeding + daincha inter cropping + AOMC with $125 \%$ soil test based NPK recorded significantly higher grain yield (4368 kg/ha) and remained on par with daincha incorporation followed by rice wet seeding + AOMC with $125(4368 \mathrm{~kg} /$ ha) and $100 \%$ (4210 kg/ha) soil test based NPK plots. The daincha incorporation followed by rice wet seeding + AOMC spray with $125 \%$ soil test based NPK application recorded significantly higher straw yield and was on par with rice wet seeding + daincha intercropping + AOMC with $125 \%$ soil test based NPK application. The combined effect of green manuring using Sesbania species and $\mathrm{N}$ fertilization on increasing the rice grain yield in Tamil Nadu was reported by many researchers (Chithra and Janaki, 1999; Janaki and Thiyagaran, 2005; Islam et al., 2019). Swarup (1987) also recorded average increase in rice grain and straw yield of 1.44 and $1.16 \mathrm{t} / \mathrm{ha}$, respectively as a result of green manuring ( $S$. aculeata) in sodic soil. Increased grain yield with the combined application of green manure +AMOC+125\% NPK and 100\% NPK in the present study could be ascribed to the improvement in root length, higher leaf $\mathrm{K}^{+}$, increased leaf soluble protein content, total soluble sugars, anti-oxidant enzymes activity, relative water content and stomatal conductance while declined of leaf $\mathrm{Na}^{+}$, electrolyte leakage, proline

Table 3. Effect of different management practices and graded level of NPK on proline content $\left(\mu g^{-1}\right)$ in rice leaf at panicle initiation and flowering stages

\begin{tabular}{|c|c|c|c|c|c|c|c|}
\hline $\begin{array}{l}\text { Main plots/ sub } \\
\text { plots }\end{array}$ & $\mathbf{M}_{1}$ & $\mathbf{M}_{2}$ & $\mathbf{M}_{3}$ & $\mathbf{M}_{4}$ & $M_{5}$ & $M_{6}$ & Mean \\
\hline \multicolumn{8}{|c|}{ Panicle initiation stage } \\
\hline Control & 250 & 232 & 264 & 264 & 298 & 300 & 268 \\
\hline $75 \%$ ST-NPK & 269 & 258 & 285 & 268 & 290 & 316 & 281 \\
\hline $100 \%$ ST-NPK & 335 & 333 & 343 & 323 & 345 & 315 & 332 \\
\hline $125 \%$ ST-NPK & 342 & 330 & 360 & 348 & 374 & 395 & 358 \\
\hline Mean & 299 & 288 & 313 & 301 & 327 & 332 & \\
\hline & $\mathbf{M}$ & $\mathbf{S}$ & $M \times S$ & $S \times M$ & & & \\
\hline$C D(P=0.05)$ & 25 & 12 & 35 & 28 & & & \\
\hline \multicolumn{8}{|l|}{ Flowering stage } \\
\hline Control & 270 & 254 & 289 & 270 & 364 & 318 & 294 \\
\hline 75 \% ST-NPK & 280 & 269 & 298 & 286 & 305 & 324 & 294 \\
\hline $100 \%$ ST-NPK & 348 & 340 & 354 & 334 & 316 & 390 & 347 \\
\hline $125 \%$ ST-NPK & 355 & 350 & 362 & 364 & 382 & 395 & 368 \\
\hline Mean & 313 & 303 & 326 & 314 & 342 & 357 & \\
\hline & $\mathbf{M}$ & $\mathbf{S}$ & $M \times S$ & $S \times M$ & & & \\
\hline$C D(P=0.05)$ & 26 & 12 & 36 & 29 & & & \\
\hline
\end{tabular}

$M_{1}$ : Transplanted rice; $M_{2}$ : Wet seeded rice; $M_{3}$ : Wet seeded rice+ Daincha incorporation; $M_{4}$ - Wet seeded rice+ Daincha intercropping; $M_{5}$ : Wet seeded rice+Daincha incorporation+AOMC; $M_{6}$ - Wet seeded rice+ Daincha intercropping+ AOMC; ST-NPK: soil test based NPK 
Janaki, P. et al. / J. Appl. \& Nat. Sci. 13(4), 1238 - 1248 (2021)

Table 4. Effect of different management practices and graded level of NPK on grain and straw yield

\begin{tabular}{|c|c|c|c|c|c|c|c|}
\hline $\begin{array}{l}\text { Main plots/ sub } \\
\text { plots }\end{array}$ & $M_{1}$ & $M_{2}$ & $M_{3}$ & $M_{4}$ & $M_{5}$ & $M_{6}$ & Mean \\
\hline \multicolumn{8}{|c|}{ Grain yield (kg/ha) } \\
\hline Control & 3099 & 2899 & 3211 & 3055 & 3828 & 3475 & 3261 \\
\hline $75 \%$ ST-NPK & 3336 & 3075 & 3523 & 3342 & 3909 & 3761 & 3491 \\
\hline $100 \%$ ST-NPK & 3535 & 3356 & 3870 & 3638 & 4258 & 3859 & 3753 \\
\hline $125 \%$ ST-NPK & 3844 & 3552 & 4073 & 3962 & 4210 & 4368 & 4002 \\
\hline \multirow[t]{2}{*}{ Mean } & 3454 & 3221 & 3669 & 3499 & 4051 & 3454 & \\
\hline & $M$ & $S$ & $M \times S$ & $S \times M$ & & & \\
\hline $\mathrm{CD}(\mathrm{P}=0.05)$ & 147 & 101 & 252 & 246 & & & \\
\hline \multicolumn{8}{|c|}{ Straw yield (kg/ha) } \\
\hline Control & 3953 & 3856 & 4055 & 3919 & 4813 & 4456 & 4175 \\
\hline $75 \%$ ST-NPK & 4138 & 3865 & 4235 & 4097 & 4933 & 4712 & 4330 \\
\hline $100 \%$ ST-NPK & 4491 & 4297 & 4779 & 4538 & 5317 & 4856 & 4713 \\
\hline $125 \%$ ST-NPK & 4935 & 4448 & 4983 & 4851 & 5675 & 5587 & 5080 \\
\hline \multirow[t]{2}{*}{ Mean } & 4379 & 4117 & 4513 & 4351 & 5189 & 4903 & \\
\hline & M & $S$ & $M \times S$ & $S \times M$ & & & \\
\hline $\mathrm{CD}(\mathrm{P}=0.05)$ & 112 & 57 & 165 & 140 & & & \\
\hline
\end{tabular}

$M_{1}$ : Transplanted rice; $M_{2}$ : Wet seeded rice; $M_{3}$ : Wet seeded rice+ Daincha incorporation; $M_{4}-$ Wet seeded rice+ Daincha intercropping; $M_{5}$ : Wet seeded rice+Daincha incorporation+ AOMC; $M_{6}$ - Wet seeded rice+Daincha intercropping+AOMC; ST-NPK: soil test based NPK

content (Osman et al., 2021). The present study observed a significant and positive correlation of grain yield with proline concentration at panicle initiation $\left(r^{2}=\right.$ $\left.0.759^{* *}\right)$ and flowering stages $\left(r^{2}=0.642^{* *}\right)$ for the wet seeding plots (Fig 1). A positive association between abiotic stress tolerance and accumulation of proline was reported by Ashraf et al. (2018). Similar to grain yield, the straw yield was significantly higher with rice wet seeding + daincha inter cropping + AOMC with $125 \%$ soil test based NPK plots and remained on par with daincha incorporation followed by rice wet seeding + AOMC with 125 (4368 kg/ha) and 100\% (4210 kg/ha) soil test based NPK plots.

In addition, the higher grain and straw yield under AOMC sprayed plots could be attributed to the higher proline content and thehigher activities of superoxide dismutase, polyphenol oxidase and catalase which increased the ability of the plants to tolerate salt stress and formulate $\mathrm{Na}^{+}$exclusion mechanism as reported by Damodaran et al. (2014). The AOMC spray might have also enhanced the defense mechanism in the rice plants due to the elevated level of enzyme activity (Ashraf and Foolad, 2007; Rais et al., 2017). Shultana et al. (2020) recorded increased rice grain yield in saline soil due to significant improvements in total chlorophyll content, relative water content (\%), total dry matter, reduction of electrolyte leakage (\%), and $\mathrm{Na} / \mathrm{K}$ ratio, when rice was inoculated with Bacillus tequilensis.

\section{Soil properties}

Imposing of different management practices in the pre- sent study with green manure, AOMC and fertilizer levels did not make any drastic variation in $\mathrm{EC}$ and $\mathrm{pH}$ of the post harvest soil except the main plot treatments influence on soil pH (Fig. 2). Daincha incorporation and intercropping significantly decreased the soil $\mathrm{pH}$ and could be ascribed to the acidifying effect of green manure decomposition. Significant reduction in soil pH due to dhiancha in situ green manuring in cotton grown sodic soil at Akola, Maharastra was also reported by Pawar et al. (2016). Similarly, the daincha incorporation followed by rice wet seeding + AOMC recorded significantly lower amount of ESP which was on par with rice wet seeding +daincha intercropping + AOMC. This could be ascribed to the reclamation effect provided by the decomposing green manure through the release of

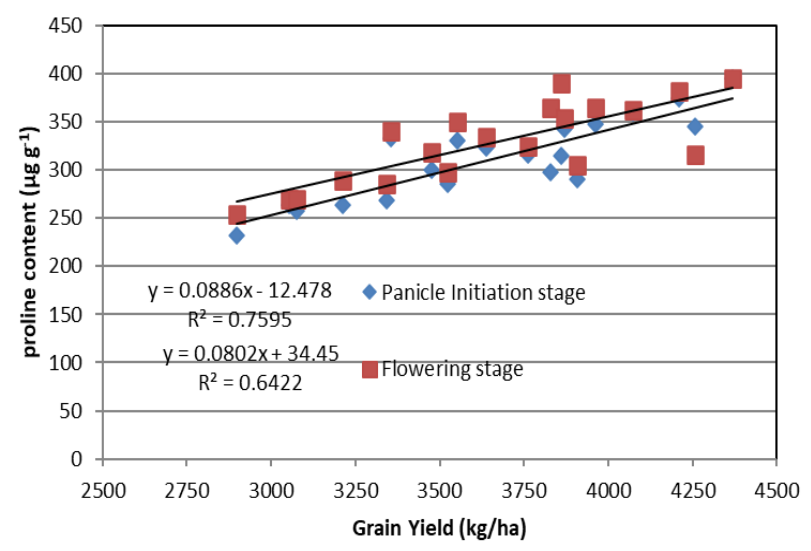

Fig. 1. Correlation plot of proline content with grain yield in the wet seeding plots 
Janaki, P. et al. / J. Appl. \& Nat. Sci. 13(4), 1238 - 1248 (2021)

Table 5. Effect of different management practices and graded level of NPK on soil enzyme activities at panicle initiation stage (60 DAS)

\begin{tabular}{|c|c|c|c|c|c|c|c|}
\hline $\begin{array}{l}\text { Main plots/ sub } \\
\text { plots }\end{array}$ & $M_{1}$ & $M_{2}$ & $M_{3}$ & $M_{4}$ & $M_{5}$ & $M_{6}$ & Mean \\
\hline \multicolumn{8}{|c|}{ Urease activity $\left(\mu \mathrm{g} \mathrm{NH}{ }^{4}-\mathrm{N}\right.$ released $\mathrm{g}^{-1}$ soil $\left.^{-1}\right)$} \\
\hline Control & 5.32 & 5.73 & 5.82 & 5.94 & 7.41 & 6.12 & 6.06 \\
\hline $75 \%$ ST-NPK & 5.75 & 5.81 & 5.92 & 6.01 & 7.82 & 6.65 & 6.33 \\
\hline $100 \%$ ST-NPK & 5.90 & 5.98 & 6.21 & 6.32 & 8.14 & 7.20 & 6.63 \\
\hline $125 \%$ ST-NPK & 6.24 & 6.12 & 6.46 & 7.42 & 8.82 & 8.24 & 7.12 \\
\hline \multirow[t]{2}{*}{ Mean } & 5.80 & 5.91 & 6.10 & 6.42 & 7.90 & 7.05 & \\
\hline & M & $S$ & $M \times S$ & $S \times M$ & & & \\
\hline$C D(P=0.05)$ & 1.07 & 0.93 & NS & NS & & & \\
\hline \multicolumn{8}{|c|}{ Phosphatase activity ( $\mu \mathrm{g}$ PNPP $\mathrm{g}^{-1}$ of soil / $\mathrm{h}$ ) } \\
\hline Control & 22.23 & 22.27 & 22.68 & 25.78 & 27.55 & 29.21 & 24.95 \\
\hline 75 \% ST-NPK & 27.30 & 28.33 & 29.32 & 29.81 & 31.82 & 30.31 & 29.48 \\
\hline 100 \% ST-NPK & 29.32 & 28.92 & 31.90 & 31.96 & 32.55 & 32.98 & 31.27 \\
\hline $125 \%$ ST-NPK & 31.45 & 33.45 & 32.41 & 32.78 & 33.56 & 33.52 & 32.86 \\
\hline \multirow[t]{2}{*}{ Mean } & 27.58 & 28.24 & 29.08 & 30.08 & 31.37 & 31.51 & \\
\hline & M & $S$ & $M \times S$ & $S \times M$ & & & \\
\hline$C D(P=0.05)$ & 1.37 & 0.98 & 1.52 & 1.60 & & & \\
\hline \multicolumn{8}{|c|}{ Dehydrogenase activity ( $\mu \mathrm{g}$ TPF released $\mathrm{g}^{-1}$ of soil $/ 24 \mathrm{~h}$ ) } \\
\hline Control & 4.13 & 4.13 & 4.12 & 4.84 & 7.84 & 6.11 & 5.20 \\
\hline 75 \% ST-NPK & 4.86 & 4.92 & 4.96 & 5.62 & 8.02 & 6.24 & 5.77 \\
\hline $100 \%$ ST-NPK & 5.15 & 5.61 & 5.61 & 6.91 & 7.11 & 6.72 & 6.19 \\
\hline $125 \%$ ST-NPK & 5.32 & 5.94 & 5.92 & 7.04 & 7.24 & 7.29 & 6.46 \\
\hline \multirow[t]{2}{*}{ Mean } & 4.87 & 5.15 & 5.15 & 6.10 & 7.55 & 6.59 & \\
\hline & M & S & $M \times S$ & $S \times M$ & & & \\
\hline$C D(P=0.05)$ & 0.87 & 0.75 & NS & NS & & & \\
\hline
\end{tabular}

$M_{1}$ : Transplanted rice; $M_{2}$ : Wet seeded rice; $M_{3}$ : Wet seeded rice+ Daincha incorporation; $M_{4}-$ Wet seeded rice+ Daincha intercropping; $M_{5}$ : Wet seeded rice+ Daincha incorporation+AOMC; $M_{6}$ - Wet seeded rice+ Daincha intercropping+ AOMC; ST-NPK: soil test based NPK

$\mathrm{CO}_{2}$, organic acids and enhanced microbial activity (Swarup, 1987). Significant increase of available NPK in soil at harvest was recorded by the daincha incorporation followed by rice wet seeding + AOMC spray (Fig.3), which might be the result of greater mineralization and mobilization of major nutrients by the decomposing products of green manure beside supplying additional $\mathrm{N}$ to the soil and for uptake (Swarup, 1987; Kumar et al., 2020). Similarly, the daincha incorporation followed by rice wet seeding + AOMC recorded significantly lower amount of ESP which was on par with rice wet seeding + daincha intercropping + AOMC (Fig. 4). The enzyme activities viz., Urease, Dehyrdogenase and Phospatases were determined in the soil at panicle initiation stage (Table 5). The activity of alkaline phosphatase was significantly higher in the soil when comparing urease and dehydrogenase activity. This is in accordance with the results of Singh et al. (2013) who reported that maximum activities of alkaline phosphatase in the soils with high $\mathrm{pH}$ which is necessary to convert the organic $P$ to available $P$ which is the main fraction of $P$ in sodic soils incorporated with green manure. Among the different management practices, daincha incorporation followed by rice wet seeding + AOMC recorded significantly higher level of enzyme activities which was on par with rice wet seeding + daincha inter cropping + AOMC. Among the sub plots, significantly higher activities of all the three enzymes were recorded by $125 \%$ soil test based NPK plot and were on par with $100 \%$ soil test based NPK plot. A significant increase of dehydrogenase activity in sodic soil due to daincha in-situ green manuring was also observed by Pawar et al. (2016) cultivated with cotton. Mallikarjun and Maity (2018) found increased urease and dehydrogenase activity in rice soil due to green manuring in the lateritic soil of west Bengal.

\section{B:C ratio}

Higher gross return, net return and $\mathrm{B}: \mathrm{C}$ ratio were obtained (Table 6 ) in the treatment combination of 
Janaki, P. et al. / J. Appl. \& Nat. Sci. 13(4), 1238 - 1248 (2021)

Table 6. Effect of different management practices and NPK fertilizer levels on the economics of rice

\begin{tabular}{|c|c|c|c|c|}
\hline Treatments & $\begin{array}{l}\text { Cost of cultivation } \\
\text { (Rs./ha) }\end{array}$ & $\begin{array}{l}\text { Gross returns } \\
\text { (Rs./ha) }\end{array}$ & $\begin{array}{l}\text { Net return } \\
\text { (Rs./ha) } \\
\end{array}$ & Benefit cost ratio \\
\hline$M_{1} S_{1}$ & 27951 & 40609 & 12658 & 1.4 \\
\hline$M_{1} S_{2}$ & 31665 & 47989 & 16324 & 1.5 \\
\hline$M_{1} S_{3}$ & 32921 & 53195 & 20274 & 1.6 \\
\hline $\mathrm{M}_{1} \mathrm{~S}_{4}$ & 34141 & 55235 & 21094 & 1.6 \\
\hline $\mathrm{M}_{2} \mathrm{~S}_{1}$ & 28501 & 54305 & 25804 & 1.9 \\
\hline $\mathrm{M}_{2} \mathrm{~S}_{2}$ & 32215 & 63249 & 31034 & 1.9 \\
\hline $\mathrm{M}_{2} \mathrm{~S}_{3}$ & 33471 & 70799 & 37328 & 2.1 \\
\hline $\mathrm{M}_{2} \mathrm{~S}_{4}$ & 34691 & 73037 & 38346 & 2.1 \\
\hline$M_{3} S_{1}$ & 29501 & 63425 & 33924 & 2.1 \\
\hline $\mathrm{M}_{3} \mathrm{~S}_{2}$ & 33215 & 75125 & 41910 & 2.2 \\
\hline $\mathrm{M}_{3} \mathrm{~S}_{3}$ & 34471 & 83065 & 48594 & 2.4 \\
\hline $\mathrm{M}_{3} \mathrm{~S}_{4}$ & 35691 & 85611 & 49920 & 2.4 \\
\hline $\mathrm{M}_{4} \mathrm{~S}_{1}$ & 29501 & 63033 & 33532 & 2.1 \\
\hline $\mathrm{M}_{4} \mathrm{~S}_{2}$ & 33215 & 73811 & 40596 & 2.2 \\
\hline $\mathrm{M}_{4} \mathrm{~S}_{3}$ & 34471 & 82893 & 48422 & 2.4 \\
\hline $\mathrm{M}_{4} \mathrm{~S}_{4}$ & 35691 & 84103 & 48412 & 2.3 \\
\hline $\mathrm{M}_{5} \mathrm{~S}_{1}$ & 32701 & 73513 & 40812 & 2.2 \\
\hline $\mathrm{M}_{5} \mathrm{~S}_{2}$ & 36415 & 88297 & 51882 & 2.4 \\
\hline $\mathrm{M}_{5} \mathrm{~S}_{3}$ & 37671 & 96463 & 58792 & 2.5 \\
\hline $\mathrm{M}_{5} \mathrm{~S}_{4}$ & 38891 & 97929 & 59038 & 2.5 \\
\hline$M_{6} S_{1}$ & 32701 & 73073 & 40372 & 2.2 \\
\hline$M_{6} S_{2}$ & 36415 & 88109 & 51694 & 2.4 \\
\hline$M_{6} S_{3}$ & 37971 & 93947 & 55976 & 2.5 \\
\hline $\mathrm{M}_{6} \mathrm{~S}_{4}$ & 38891 & 95287 & 56396 & 2.4 \\
\hline
\end{tabular}

$M_{1}$ : Transplanted rice; $M_{2}$ : Wet seeded rice; $M_{3}$ : Wet seeded rice+ Daincha incorporation; $M_{4}-$ Wet seeded rice+Daincha intercropping; $M_{5}$ : Wet seeded rice+ Daincha incorporation+AOMC; $M_{6}$ - Wet seeded rice+ Daincha intercropping+ AOMC; $S_{1}:$ Control ; $S_{2}: 75 \%$ soil test based NPK ; $\mathrm{S}_{3}: 100 \%$ soil test based NPK ; $\mathrm{S}_{4}: 125 \%$ soil test based NPK

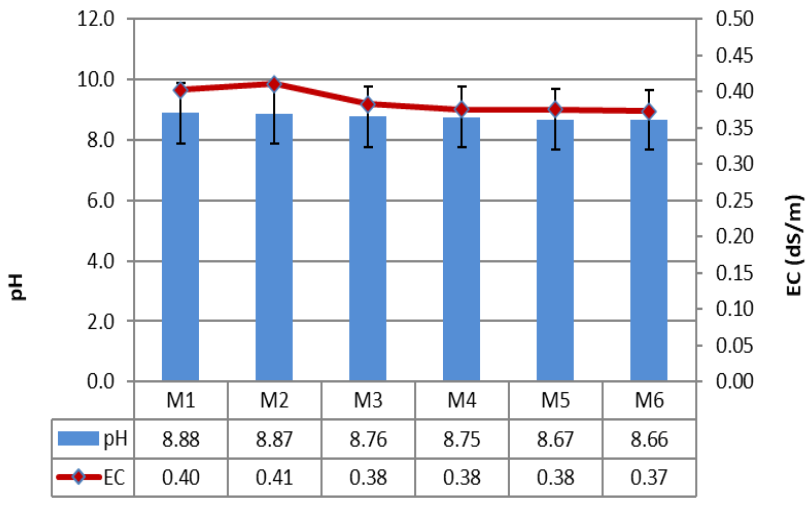

Treatments
$\mathrm{M}_{1}$ : Transplanted rice; $\mathrm{M}_{2}$ : Wet seeded rice; $\mathrm{M}_{3}$ : Wet seeded rice+Daincha incorporation; $M_{4}$ - Wet seeded rice+Daincha intercropping; $M_{5}$ : Wet seeded rice+Daincha incorporation+AOMC; $\mathrm{M}_{6^{-}}$Wet seeded rice+Daincha intercropping+AOMC

Fig. 2. Effect of different soil and crop management practices on soil $\mathrm{pH}$ and electrical conductivity at harvest daincha incorporation followed by rice wet seeding + AOMC with $125 \%$ soil test based NPK which remained on par with daincha incorporation followed by rice wet seeding + AOMC with $100 \%$ soil test based NPK and rice wet seeding + daincha inter cropping + AOMC with125\% soil test based NPK application. Since B:C ratio is on par for 100 and $125 \%$ NPK applied plots, the daincha incorporation followed by rice wet seeding + AOMC spray with $100 \%$ NPK fertilizer application could be considered as the best and optimum management option for growing wet seeded rice in sodic soil under water scarce condition. Always the additional $\mathrm{N}$ application is recommended to cultivate crops in saltaffected soil which will be met by the green manure addition in the present study. The higher net return and $\mathrm{B}: \mathrm{C}$ ratio due to $\mathrm{AOMC}$ spray could be ascribed to the improved defense mechanism in rice for salt stress. Singh et al. (2016) found that the additional net-gain became negative when $\mathrm{N}$ application is increased 


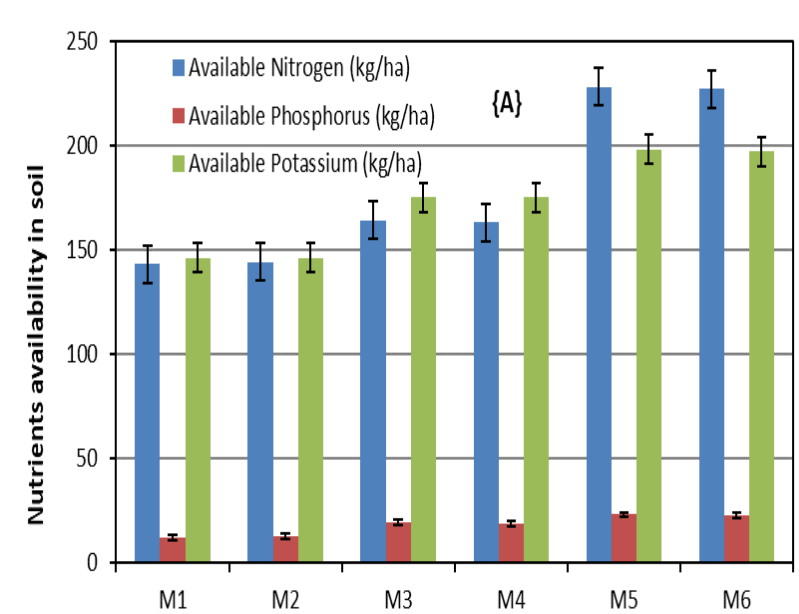

$M_{1}$ : Transplanted rice; $M_{2}$ : Wet seeded rice; $M_{3}$ : Wet seeded rice+Daincha incorporation; $\mathrm{M}_{4}$ - Wet seeded rice+Daincha intercropping; $M_{5}$ : Wet seeded rice+Daincha incorporation+AOMC; $\mathrm{M}_{6^{-}}$Wet seeded rice+Daincha intercropping+AOMC

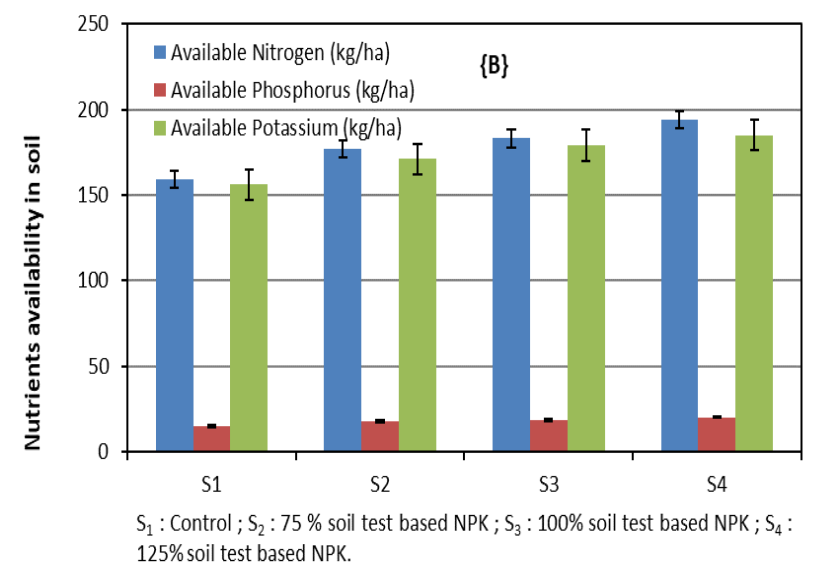

Fig. 3. Effect of different soil and crop management practices $\{A\}$ and graded levels of NPK fertilizer $\{B\}$ on availability of major nutrients in soil at harvest

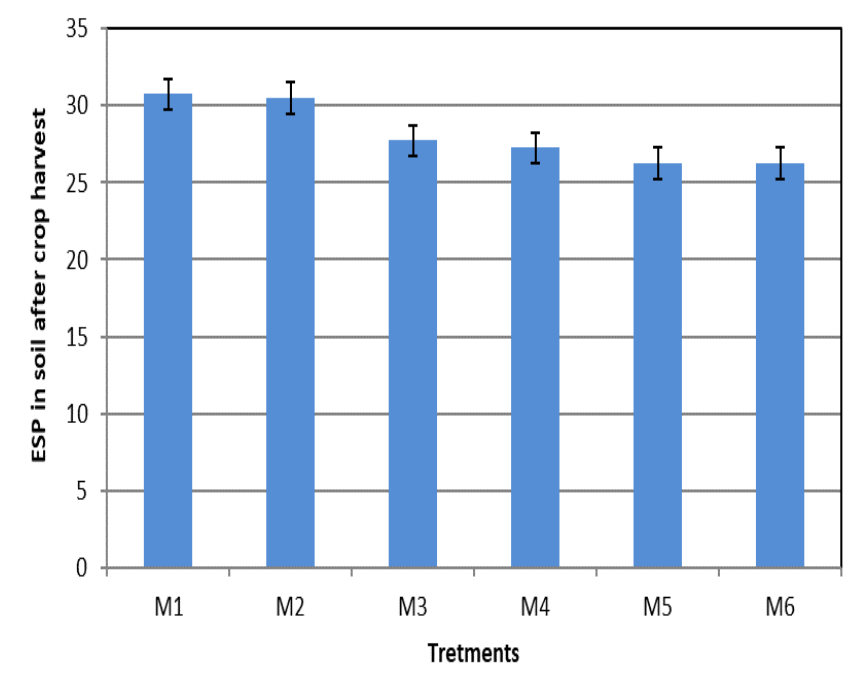

Fig. 4. Effect of different soil and crop management practices and graded levels of NPK fertilizer on exchangeable sodium percent (ESP) in soil at harvest above optimum and reported decreasing returns from additional $\mathrm{N}$ in sodic soil grown with rice at Lucknow, India. Mohamed Faten and Abou-Zeid (2011) also found a reduction of about $25 \%$ of recommended dose of NPK for rice cultivation due to the application of diazotrophs and plant growth-promoting rhizobacteria isolated from saline-sodic soil.

\section{Conclusion}

The present study concluded that the daincha incorporation @ 6.25 t/ha followed by rice wet seeding and anti oxidant microbial consortia foliar spray @1.5\% at boot leaf and panicle initiation stages of rice with 100 or 125 $\%$ soil test based NPK was effective in improving the rice productivity in sodic soil under water-scarce conditions. Besides significant reduction in ESP and increase of phosphatase enzyme activity in sodic soil due to dhaincha incorporation was observed. The influence of the combined application of green manure and AMOC spray @1.5 \% spray on enhancing the ectophytic microbial population in rice plants and changes in the activity of enzymes like glutathione and metabolic and physiological variation in rice plants needs to be explored. Detailed research on this line will help to transform these technologies to other crops grown under water-scarce conditions in sodic soil to enhance the production and productivity under semi-arid situations.

\section{ACKNOWLEDGEMENTS}

The authors wish to express their profound gratitude the Dean, Anbil Dharmalingam Agricultural College \& Research Institute, Tamil Nadu Agricultural University, Trichy for providing facilities for conducting the field experiment and laboratory analysis work.

\section{Conflict of interest}

The authors declare that they have no conflict of interest.

\section{REFERENCES}

1. Amrutha, K.K. \& Santhy, P. (2018). Influence of different management practices and fertilizer levels on the growth and yield of rice in sodic soil. Madras Agric. J., 105, 4449.

2. Ansary, M.H., Rahmani, H.A., Ardakani, M.R., Paknejad, F., Habibi, D. \& Mafakheri, S. (2012). Effect of Pseudomonas fluorescent on proline and phytohormonal status of maize (Zea mays L.) under water deficit stress. Annal Biol. Res., 3, 1054-1062.

3. Arora, M., Kaushik, A., Rani, N.\& Kaushik, C.P. (2010) Effect of cyano-bacterial exopolysaccharides on salt stress alleviation and seed germination. J. Environ. Biol., 31, 701-704.

4. Ashraf, M. \& Foolad, M.R. 2007. Roles of glycine, betaine 
and proline in improving plant abiotic stress resistance. Environ Exp Bot., 59, 206-216.

5. Ashraf, M. A., Iqbal, M., Rasheed, R., Hussain, I., Perveen, S. \& Mahmood, S. (2018). Dynamic proline metabolism: Importance and Regulation in Water Limited Environments. In: Plant metabolites and regulation under environmental stress, Copyright (C) 2018 Elsevier Inc., 323336. doi:10.1016/b978-0-12-812689-9.00016-9

6. Bates, L.S., Waldren, R.P. \&Teare, I.D. (1973). Rapid determination of free proline for water-stress studies. Plant Soil, 39, 205-207.https://doi.org/10.1007 / BF00018060

7. Bray, E.A., Bailey-Serres, J. \&Weretilnyk, E. (2000) Responses to abiotic stresses. In: Buchanan BB, Gruissem W, Jones RL (eds) Biochemistry and molecular biology of plants. American Society of Plant Physiologists, Rockville, pp 1158-1203

8. Casida, J.r., L. E., Klein, D. A. \& Santoro, T. (1964). Soil dehydrogenase activity. Sscience, 98, 371-376.

9. Chen,T., Shabala, S., Niu, Y., Chen, Z.H.,Shabala, L., Meinke, H., Venkataraman, G., Pareek, A., Xu, J. \& Zhou, M. (2021). Molecular mechanisms of salinity tolerance in rice, The Crop Journal, 9, 506-520.

10. Chithra, L. \& Janaki, P. (1999). Combined effect of organic wastes and inorganic nutrients on the nutrient uptake and yield of rice in kar and pishanam seasons. Oryza 36, 327-330

11. Damodaran, T., Rai, R.B., Jha, S.K., Kannan, R., Pandey, B.K.,Vijayalaxmi Sah, Mishra, V.K. \& Sharma, D.K. (2014) Rhizosphere and endophytic bacteria for induction of salt tolerance in gladiolus grown in sodic soils, Journal of Plant Interactions, $\quad 9, \quad 577-584, \quad$ DOI: 10.1080/17429145.2013.873958.

12. Gomez, K. A. \&A. A. Gomez. (2010). Statistical Procedures for Agricultural Research. International Rice Research Institute. A Wiley-interscience Publication. Johnwiley\& Sons, New York.

13. Islam, M.M., Urmi, T.A., Rana, M.S., Alam, M.S. \& Haque, M.M. (2019). Green manuring effects on crop morphophysiological characters, rice yield and soil properties. Physiol. Mol. Biol. Plants, 25, 303-312. https:// doi.org/10.1007/s12298-018-0624-2

14. Jackson, M.L. (1973). Soil chemical analysis.Prentice Hall of India Pvt.Ltd., NewDelhi. II ${ }^{\text {nd }}$ Indian reprint.1-498.

15. Janaki, P. \&Thiyagarajan, T.M. (2005). Effect of $\mathrm{N}$ management approaches and planting densities on nitrogen accumulation by transplanted rice. Acta Agronomica Hungarica, 53, 405-415.

16. Janaki, P., Thiyagarajan, T.M. \& V Balasubramanian. (2000). Effect of planting density on chlorophyll meterbased $\mathrm{N}$ management in transplanted rice. International Rice Research Notes., 25, 24-27.

17. Janaki, P., Brindhavani, P.M, \& D. Udhayanandini. (2020). Standard methods of characterizing saline/sodic soils and poor quality water. In: Book on "Technological Advances in enhancing productivity of salt affected soils. Today and Tomorrow's Printers \& Publishers. Daryaganj, New Delhi 110 002. ISBN. 9788170196686.

18. Kumar, P. \& Sharma, P.K. (2020) Soil salinity and food security in India. Front. Sustain. Food Syst., 4, 533781. doi: $10.3389 /$ fsufs. 2020.533781

19. Kumar, S., Samiksha, \& Sukul, P. (2020). Green manuring and its role in soil health management. B. Giri, A. Varma (eds.), Soil Health, Soil Biology, 59, 219-241. Springer Nature Switzerland AG 2020. 10.1007/978-3-030-443641_13.Latha, M.R. \& Janaki, P. (2015). Problem soils and their management. In: Hand Book on e-Velanmai for Extension Professionals Edtd. C. Karthikeyan, H. Philip and M. Senthil Kumar. Published a by TNAU offset Printing Press, Coimbatore. ISBN No: 978-93-83799-23-7.

20. Lou, W.P., Wu, L.H., Chen, H.Y. \& Ji, Z.W. (2012). Assessment of rice yield loss due to torrential rain: A case study of Yuhang Country, Zhejiang Province, China. Natural Hazards, 60, 311-320.

21. Mallikarjun, M. \&Maity, S.K. (2018). Effect of integrated nutrient management on soil biological properties in kharif rice. Int. J. Curr. Microbiol. App. Sci., 7, 1531-1537.

22. MohamedFaten, M. \& Abou-Zeid, M. Y.(2011). Integrated effect of some biofertilizers and proline for improvement of rice productivity under saline sodic soil conditions. Egypt . J. of Appl. Sci., 26, 363-378.

23. Natarajan, S.K., Zhu, W., Liang, X., Zhang, L., Demers, A.J., Zimmerman, M.C., Simpson, M.A. \& Becker, D.F. (2012). Proline dehydrogenase is essential for proline protection against hydrogen peroxide-induced cell death. Free Radic. Biol. Med., 53,1181-1191. http:// dx.doi.org/10.1016/j.freeradbiomed.2012.07.002.

24. Osman, H.S., Salah M. G., Mohssen E., Alaa E.D.O., Ahmed M.A.E., Usama A. A. \& Emad M. H.(2021). Interactive Impacts of beneficial microbes and Si-Zn nanocomposite on growth and productivity of soybean subjected to water deficit under salt-affected soil conditions. Plants, 10, 1396. https://doi.org/10.3390/plants 10071396

25. Pawar S. K., Kumbhar, G. A. \& Dahiphale, S. B. (2016). The effect of crop residues, green manuring and gypsum on sequestration of carbon in soils of Purna Valley. International Journal of Science and Research, 7(4): 15491553.

26. Rahman, A., S. B., Nahar, K., Jubayer Mahmud, A., Hasanuzzaman, M., Hossain, S. and Fujita, M. (2017). Salt stress tolerance in rice: emerging role of exogenous phytoprotectants. In: Jinquan Li (Eds.), Advances in International Rice Research-March 2017. https://doi.or $\mathrm{g} / 10.5772 / 67098$

27. Rais, A., Jabeen, Z., Shair, F., Hafeez, F. Y. \& Hassan, M. N. (2017). Bacillus spp., a bio-control agent enhances the activity of anti-oxidant defense enzymes in rice against Pyriculariaoryzae. PloS one, 12, e0187412. https://doi.o rg/10.1371/journal.pone.0187412

28. Sajid Hussain, Jun-huaZhang, Chu Zhong, Lian-feng Zhu, Xiao-chuang Cao, Sheng-miaoYu, James Allen Bohr, JijieHu \& Qian-yuJin. (2017). Effects of salt stress on rice growth, development characteristics, and the regulating ways: A review, Journal of Integrative Agriculture, 16, 2357-2374, https://doi.org/10.1016/S2095-3119(16)61608 $-8$.

29. Shultana, R, Ali Tan Kee Zuan, Mohd R. Yusop, Halimi Mohd Saud, \& Ayanda, A.F. (2020). Effect of salt-tolerant bacterial inoculations on rice seedlings differing in salttolerance under saline soil conditions. Agronomy 10, 1030. doi:10.3390/agronomy 10071030.

30. Singh, K., Singh, B., \& Singh, R. R. (2013). Effect of land rehabilitation on physico-chemical and microbial properties of a sodic soil. CATENA, 109, 49-57. doi:10.1016/ 
j.catena.2013.05.006.

31. Singh, Y.P., Mishra, V.K., Sudhanshu Singh, Sharma, D.K., Singh, D., Singh, U.S., Singh, R.K., Haefele, S.M. \& Ismail, A.M.(2016). Productivity of sodic soils can be enhanced through the use of salt tolerant rice varieties and proper agronomic practices, Field Crops Research, 190:82-90, https://doi.org/10.1016 /j.fcr.2016.02.007.

32. Swarup, A. (1987). Effect of presubmergence and green manuring (Sesbania aculeata) on nutrition and yield of wetland rice (Oryza sativa L.) on a sodic soil. Biology and
Fertility of Soils, 5, 203-208.

33. Tabatabai, M. A. \&Bremner, J. M. (1969).Use of p-nitrophenyl phosphate for assay of soil phosphatase activity. Soil Biology and Biochemistry, 1, 301-307.

34. Tabatabai, M. A. \& Bremner, J. M. (1972). Assay of urease activity in soils. Soil Biology and Biochemistry, 4, 479487.

35. Yoshida, S., Forno, D. A. \& Cock, J. H. (1971). Laboratory manual for physiological studies of rice. IRRI, Philippines, pp.36- 37 